\title{
Hubungan Self Concept dan Self Confidence
}

\author{
Sholiha ${ }^{1)}$ \\ Fakultas Psikologi Universitas Yudharta Pasuruan \\ Email: fpsi@yudharta.ac.id \\ Lailatuzzahro Al-Akhda Aulia ${ }^{2}$ \\ Fakultas Psikologi Universitas Yudharta Pasuruan \\ Email: kalyla.zahra@yudharta.ac.id
}

\begin{abstract}
A confidence and an attitude toward a persons ability to accept both positive and negative that are shaped and learned through the process of studying with a view to his own happiness. While self concept is an idea, mind, feeling, belief and position known by the individual in relating to others. The purpose of this study is to know a self concept relationship with a self confident. The hypothesis of this study is there's a self concept relationship with a self confidence. In the study, researchers used a quantitative approach in an attempt to test hypotheses that had been drafted. The subject in this study is a teenager sitting in class 7 and 8 MTS miftahul ulum pandaan. The sampling technique used was staggerate stratified random sampling. The analysis of data in this study uses the scale of self concept and self confidence. Data analysis was calculated by using product moment Pearson and acquired rxy by 0.657 with an rtab $1 \%$ of 0.254 . Thus there is a highly significant correlation between self concept and a self confidence.
\end{abstract}

Keywords: Self Concept, Self Confidence, Teen

Abstrak. Self confidence merupakan suatu keyakinan dan sikap seseorang terhadap kemampuan pada dirinya sendiri dengan menerima secara apa adanya baik positif maupun negatif yang dibentuk dan dipelajari melalui proses belajar dengan tujuan untuk kebahagiaan dirinya. Sedangkan self concept merupakan ide, pikiran, perasaan, kepercayaan dan pendirian yang diketahui oleh individu dalam berhubungan dengan orang lain. Tujuan penelitian ini yaitu untuk mengetahui hubungan self concept dengan self confidence. Hipotesis dalam penelitian ini adalah ada hubungan self concept dengan self confidence. Di dalam penelitian ini, peneliti menggunakan pendekatan kuantitatif dalam usaha menguji hipotesis yang telah disusun. Sedangkan subyek dalam penelitian ini adalah remaja yang duduk di bangku sekolah kelas VII dan VIII Mts Miftahul Ulum Pandaan. Teknik pengambilan sampel yang digunakan yaitu proportionate stratified random sampling. Pengambilan data dalam penelitian ini menggunakan skala sikap self concept dan self confidence. Analisis data dihitung dengan menggunakan teknik korelasi product moment Pearson dan diperoleh Rxy sebesar 0,657 dengan $\mathrm{R}$ tab $1 \%$ sebesar 0,254 . Dengan demikian ada korelasi yang sangat signifikan antara self concept dengan self confidence.

Kata Kunci: Self Concept, Self Confidence, Remaja 
Masa remaja merupakan masa terjadinya krisis identitas atau pencariaan identitas diri, individu dihadapkan dengan temuan siapa mereka, bagaimana mereka kira-kira nantinya dan kemana mereka menuju kehidupannya (Erickson, dalam Santrock 1995). Gagasan Erickson ini dikuatkan oleh Marcia yang menemukan bahwa ada empat status identitas diri pada remaja, sedangkan tahapan remaja terdiri dari remaja awal dan remaja akhir (Santrock, 1995).

Remaja awal pada tahap usia 1215 tahun pada usia ini biasanya remaja yang duduk di bangku SMP. Remaja pada tahap usia ini berusaha untuk menemukan jati dirinya. Dengan kata lain individu mengalami krisis identitas. Remaja membutuhkan interaksi dengan orang lain dalam proses pencarian jati diri, yaitu teman sebaya, sekolah, orang tua maupun masyarakat. Bentuk interaksi remaja di sekolah salah satunya dengan mengikuti organisasi yang ada di sekolah.

Dalam kenyataannya, untuk berinteraksi dengan orang lain individu harus mempunyai keberanian atau percaya diri (Putri dan Hadi, 2005). Dalam lingkungan sekolah ketika seorang guru memberikan kesempatan untuk bertanya kepada siswanya, terkadang seorang pelajar malu untuk bertanya, dimana disebabkan oleh kurangnya rasa percaya diri yang dimiliki siswa tersebut. Rasa percaya diri atau yang biasa disebut juga dengan istilah self confidence terkait dengan dua hal yang paling mendasar dalam praktek hidup. Yang pertama adalah, self confidence terkait dengan bagaimana seseorang memperjuangkan keinginannya untuk meraih sesuatu (prestasi atau performance). Selanjutnya, yang kedua, self confidence terkait dengan kemampuan seseorang dalam menghadapi masalah yang menghambat perjuangannya. Orang yang kepercayaan dirinya bagus akan cenderung berkesimpulan bahwa dirinya "lebih besar" dari masalahnya. Sebaliknya, orang yang memiliki rasa percaya diri rendah akan cenderung berkesimpulan bahwa masalahnya jauh lebih besar dari dirinya. Self confidence dapat dikembangkan 
dengan adanya bantuan dari lingkungan (Iswidharmanajaya, 2004). Sekolah memiliki organisasi yang dapat berpengaruh terhadap self confidence siswa. Menurut Kurnia (2005, dalam Kusumawati, 2009), mengikuti organisasi merupakan salah satu upaya untuk pengembangan diri, dan melatih keterampilan berbicara di depan umum. Remaja dapat mengembangkan diri dengan menyalurkan bakat serta kreativitas yang telah dimilikinya. Adanya keterlibatan dengan organisasi juga merupakan satu upaya cukup baik untuk mengasah self confidence, yaitu melalui pergaulan dengan teman sebaya.

Seperti siswa pada Mts Miftahul Ulum ini mereka kebanyakan siswa yang sulit untuk tampil di depan umum, karena memiliki rasa percaya diri yang kurang. Hal yang terjadi adalah keadaan sekolahan yang berada di desa dan kurangnya interaksi atau kegiatan yang membangun semangat siswa. Rasa tidak percaya diri siswa nampak terlihat ketika seorang siswa disuruh untuk membaca di depan kelas, sering kali siswa menolak, ada juga siswa yang minder ketika berkumpul sesama temannya namun ada salah satu teman yang mungkin lebih pandai. Adalagi kejadian yang sering terjadi seorang siswa yang ketahuan mencontek hasil ulangan atau tes, kebanyakan siswa malah lebih memilih jawaban temannya karena merasa tidak percaya diri dengan jawaban yang dipilihnya.

Masa remaja juga merupakan periode dimana individu menggunakan kemampuannya untuk memberi dan menerima dalam berkomunikasi dengan orang lain dan mempercayai mereka untuk belajar mengenai apa yang tidak baik dan apa yang baik sesuai dengan tugas perkembangannya. Remaja dituntut untuk lebih belajar menyesuaikan diri dalam hubungan sosial yang lebih luas dan majemuk. Akan tetapi banyak remaja mengalami kesulitan dalam penyesuaian sosial yang berkaitan dengan komunikasi dengan orang lain. Hal ini dapat dilihat dalam perilaku antara lain, tidak bisa mengeluarkan pendapat, kurang percaya diri, pesimis dan cenderung menutup diri, sehingga mengakibatkan mereka kesulitan 
berkomunikasi dengan berbagai pihak. Sedangkan salah satu cara dalam berkomunikasi dengan orang lain perlu adanya ungkapan. Karena dengan pengungkapan diri merupakan cara untuk memulai dan memelihara suatu komunikasi. Untuk dapat mengungkapkan diri, tentu saja harus memahami diri yaitu menyadari dan mengetahui perasaan, siapa dirinya, kualitas diri, dan harapanharapan diri. Sedangkan dalam memahami diri seseorang perlu mempunyai konsep diri yang baik supaya mempunyai rasa percaya diri yang baik pula. Sedangkan untuk mempunyai rasa percaya diri yang baik seorang individu membutuhkan konsep diri yang positif.

Konsep diri merupakan penentu sikap individu dalam bertingkah laku, artinya apabila individu cenderung berpikir akan berhasil, maka hal ini merupakan kekuatan atau dorongan yang akan membuat individu menuju kesuksesan. Sebaliknya, jika individu berpikir akan gagal, maka hal ini sama saja sudah mempersiapkan pintu kegagalan bagi dirinya. Maka dari itu konsep diri individu dapat menentukan keberhasilan dalam perkembangan individu.

Konsep diri seseorang dinyatakan melalui sikap dirinya yang merupakan aktualisasi orang tersebut. Manusia sebagai organisme yang memiliki dorongan untuk berkembang yang pada akhirnya menyebabkan ia sadar akan keberadaan dirinya. Perkembangan yang berlangsung tersebut kemudian membantu pembentukan konsep diri individu yang bersangkutan. Konsep diri merupakan bagian dari diri yang mempengaruhi setiap pengalaman, pikiran, perasaan, dan tingkah laku (keberhasilan) seseorang, karena individu bertingkah laku sesuai dengan konsep dirinya. Dan kualitas perilaku ditentukan tinggi rendahnya konsep diri. Individu yang berkonsep diri tinggi cenderung mempunyai sikap yang terbuka dan mudah mengemukakan pendapat, begitu pula sebaliknya.

Salah satu faktor yang sangat menentukan apakah seseorang akan berperilaku negative atau positif adalah dari konsep diri, sebab perilaku negative merupakan perwujudan 
adannya gangguan dalam usaha pencapaian konsep diri, apabila seseorang gagal dalam pencapian konsep diri maka ia akan merasa kecewa dalam diri dan lingkungannya. Sehingga ia akan memandang dirinya dengan sikap negative yang mana orang tersebut akan mengalami rasa kurang percaya diri. Sebaliknya, apabila seseorang berhasil dalam mencapai konsep dirinya maka mereka akan merasa puas dengan dirinya maupun terhadap lingkungannya. Sehinggga akan membuat ia bersikap positif terhadap dirinya dan akan merasa lebih percaya diri dalam lingkungan.

Berdasarkan fenomena diatas muncul pertanyaan apakah ada hubungan self concept dengan self confidence. Penelitian ini diharapkan dapat memberikan manfaat dalam membantu mengembangkan keilmuan di bidang psikologi pendidikan tentang kepercayaan diri siswa.

\section{Self Confidence}

Miskell (dalam Anggelis, 1997) mendefinisikan percaya diri sebagai kepercayaan akan kemampuan sendiri yang memadai dan menyadari kemampuan yang dimiliki, serta dapat memanfaatkannya secara tepat. Selanjutnya, Maslow (dalam Alwisol, 2004) menyebutkan percaya diri merupakan modal dasar untuk pengembangan aktualitas diri. Dengan percaya diri orang akan mampu mengenal dan memahami diri sendiri. Sementara itu, kurangnya percaya diri akan menghambat pengembangan potensi diri. Jadi orang yang kurang percaya diri akan menjadi seseorang yang pesimis dalam menghadapi tantangan, takut dan ragu-ragu untuk menyampaikan gagasan, serta bimbang dalam menentukan pilihan dan sering membanding-bandingkan dirinya dengan orang lain.

Percayaan diri merupakan suatu keyakinan dan sikap seseorang terhadap kemampuan pada dirinya sendiri dengan menerima secara apa adanya baik positif maupun negatif yang dibentuk dan dipelajari melalui proses belajar dengan tujuan untuk kebahagiaan dirinya. Percaya diri adalah modal dasar seorang manusia dalam memenuhi berbagai kebutuhan sendiri. Seseorang mempunyai 
kebutuhan untuk kebebasan berfikir dan berperasaan sehingga seseorang yang mempunyai kebebasan berfikir dan berperasaan akan tumbuh menjadi manusia dengan rasa percaya diri. Salah satu langkah pertama dan utama dalam membangun rasa percaya diri dengan memahami dan meyakini bahwa setiap manusia memiliki kelebihan dan kelemahan masingmasing. Kelebihan yang ada didalam diri seseorang harus dikembangkan dan dimanfaatkan agar menjadi produktif dan berguna bagi orang lain.

Pendapat lain mengatakan percaya diri merupakan suatu keyakinan dan sikap seseorang terhadap kemampuan pada dirinya sendiri dengan menerima secara apa adanya baik positif maupun negatif yang dibentuk dan dipelajari melalui proses belajar dengan tujuan untuk kebahagiaan dirinya. Seseorang yang percaya diri dapat menyelesaikan tugas atau pekerjaan yang sesuai dengan tahapan perkembangan dengan baik, merasa berharga, mempunyai keberanian, dan kemampuan untuk meningkatkan prestasinya, memper-timbangkan berbagai pilihan, serta membuat keputusan sendiri merupakan perilaku yang mencerminkan percaya diri (Widarso, 2005).

Berdasarkan paparan tentang percaya diri, dapat kesimpulan bahwa percaya diri adalah kondisi mental atau psikologis dimana individu dapat mengevaluasi keseluruhan dari dirinya sehingga memberi keyakinan kuat pada kemampuan dirinya untuk melakukan tindakan dalam mencapai berbagai tujuan di dalam hidupnya.

Self Concept

Menurut Burns (1993), konsep diri adalah suatu gambaran campuran dari apa yang kita pikirkan, bagaimana pendapat orang lain mengenai diri kita, dan seperti apa diri kita yang kita inginkan. Konsep diri adalah pandangan individu mengenai siapa diri individu tersebut, dan hal tersebut bisa diperoleh lewat informasi yang diberikan lewat orang lain pada diri individu tersebut. Rochman Natawidjaya (dalam Adiyanti 2006) menjelaskan bahwa konsep diri adalah persepsi individu tentang dirinya, kemampuan dan ketidak- 
mampuannya, tabiat-tabiatnya, harga dirinya dan hubungannya dengan orang lain.

\section{Selanjutnya Hurlock}

memberikan pengertian tentang konsep diri sebagai gambaran yang dimiliki orang tentang dirinya. Konsep diri ini merupakan gabungan dari keyakinan yang dimiliki individu tentang mereka sendiri yang meliputi karakteristik fisik, psikologis, sosial, emosional, aspirasi dan prestasi.

Konsep diri juga merupakan ide, pikiran, perasaan, kepercayaan dan pendirian yang diketahui oleh individu dalam berhubungan dengan orang lain. Konsep diri berkembang secara bertahap dimulai dari bayi dapat mengenali dan membedakan oranglain. Proses yang berkesinambungan dari perkembangan konsep diri dipengaruhi oleh pengalaman interpersonal dan kultural yang memberikan perasaan positif, memahami kompetensi pada area yang bernilai bagi individu dan dipelajari melalui akumulasi kontakkontak sosial dan pengalaman dengan orang lain.
Dari beberapa pendapat dari para ahli di atas maka dapat disimpulkan bahwa pengertian konsep diri adalah cara pandang secara menyeluruh tentang dirinya, yang meliputi kemampuan yang dimiliki, perasaan yang dialami, kondisi fisik dirinya maupun lingkungan terdekatnya.

Burn (1993) menyatakan yang mempengaruhi timbulnya self confidence, salah satunya yaitu konsep diri. Untuk menjadi pribadi yang memiliki rasa percaya diri, seorang individu membutuhkan konsep diri yang positif. Konsep diri merupakan gambaran yang dipegang seseorang menyangkut dirinya sendiri. Jika seorang individu sudah mengenal keadaan dirinya dan dapat menerima kelebihan dan kekurangan yang dimiliki maka individu tersebut akan memiliki percaya diri yang baik.

Hariyanto (2010) dalam Wahid (2014) mengemukakan bahwa individu yang memiliki konsep diri positif akan bersikap optimis, percaya terhadap diri sendiri dan selalu bersikap positif terhadap segala sesuatu, juga terhadap kegagalan yang dialami. Kegagalan 
tidak dipandang sebagai akhir segalanya, namun dijadikan sebagai penemuan dan pelajaran berharga untuk melangkah kedepan. Individu yang memiliki konsep diri positif akan mampu menghargai dirinya sendiri dan melihat hal-hal yang positif yang dapat dilakukan demi keberhasilan di masa yang akan datang. Individu yang memiliki konsep diri positif dalam segala sesuatunya akan menanggapinya secara positif, dapat memahami dan menerima sejumlah fakta yang sangat bermacam-macam tentang dirinya sendiri. Ia akan percaya diri, akan bersikap yakin dalam bertindak dan berperilaku. Sedangkan individu yang memiliki konsep diri negatif akan menanggapi segala sesuatu dengan pandangan negatif pula, dia akan mengubah terus menerus konsep dirinya atau melindungi konsep dirinya itu secara kokoh dengan cara mengubah atau menolak informasi baru dari lingkungannya.

Terbentuknya kepercayaan diri pada seseorang diawali dengan perkembangan konsep diri yang diperoleh dalam pergaulan suatu kelompok. Menurut Centi (1995), konsep diri merupakan gagasan tentang dirinya sendiri. Seseorang yang mempunyai rasa rendah diri biasanya mempunyai konsep diri negatif, sebaliknya orang yang mempunyai rasa percaya diri akan memiliki konsep diri positif.

$$
\text { Menurut Rahmat }
$$

kepercayaan diri dapat diartikan sebagai suatu kepercayaan terhadap diri sendiri yang dimiliki oleh setiap orang dalam kehidupannya serta bagaimana orang tersebut memandang dirinya secara utuh dengan mengacu pada konsep diri. Ketakutan untuk melakukan komunikasi dikenal sebagai communication apprehension. Orang yang aprehensif dalam komunikasi disebabkan oleh kurangnya rasa percaya diri.

Individu yang memiliki konsep diri positif akan bersikap optimis, percaya tehadap diri sendiri dan selalu bersikap positif terhadap segala sesuatu, juga terhadap kegagalan yang dialami. Kegagalan tidak dipandang sebagai akhir segalanya, namun dijadikan sebagai penemuan dan pelajaran berharga untuk melangkah 
kedepan serta menjadi lebih berani dan tampil lebih percaya diri. Individu yang memiliki konsep diri positif akan mampu melakukan apapun artinya seseorang akan percaya diri tidak malu jika ingin mengaktualisasikan dirinya sendiri atau ingin berkreasi, dan melihat hal-hal yang positif yang dapat dilakukan demi keberhasilan di masa yang akan datang. Percaya Diri adalah kondisi mental atau psikologis diri seseorang yang memberi keyakinan kuat pada dirinya untuk berbuat atau melakukan sesuatu tindakan. Orang yang tidak percaya diri adalah orang yang memiliki konsep diri negatif, kurang percaya pada kemampuannya.

Berdasarkan paparan di atas, hipotesis dalam penelitian ini adalah ada hubungan self concept dengan self confidence.

\section{Metode}

Penelitian ini menggunakan pendekatan kuantitatif dalam usaha menguji hipotesis yang telah disusun. Sedangkan subyek dalam penelitian ini adalah remaja yang duduk di bangku sekolah kelas VII dan VIII Mts
Miftahul Ulum Pandaan. Sedangkan teknik pengambilan sampel yang digunakan dalam penelitian ini adalah proportionate stratified random sampling, teknik ini digunakan bila populasi mempunyai anggota atau unsur yang tidak homogen dan berstrata secara proporsional. Dengan demikian, dari keseluruhan jumlah siswa, maka di ambil 60 sampel siswa untuk dijadikan sampel penelitian.

Pengambilan data dalam penelitian ini menggunakan skala sikap self concept dan skala self confidence. Teknik analisis data yang digunakan dalam penelitian ini yaitu dengan menggunakan teknik korelasi product moment Pearson.

\section{Hasil}

Dari hasil perhitungan korelasi poduct moment Pearson diperoleh nilai rxy sebesar 0,657 dengan $r$ tab 1\% sebesar 0,254 dengan dimikian ada korelasi yang sangat signifikan antara self concept dengan self confidence artinya semakin tinggi self concept dan maka semakin tinggi pula self confidence begitu pula sebaliknya 
semakin rendah self concept maka semakin tinggi pula self confidence dari perhitungan diperoleh persamaan garis regresi sebagai berikut:

Tabel 1. Ringkasan Analisis Regresi

\begin{tabular}{|c|c|c|c|c|c|}
\hline $\begin{array}{c}\text { Sumber } \\
\text { varians }\end{array}$ & db & JK & RK & Freg & F tab 1\% \\
\hline $\begin{array}{c}\text { Regresi } \\
\text { (reg) }\end{array}$ & 1 & 482630,568 & 482630,568 & 58,54 & 7,31 \\
\hline $\begin{array}{c}\text { Residu } \\
\text { (res) }\end{array}$ & 58 & $-478168,918$ & 8244,29 & - & 3,51 \\
\hline Total (T) & 59 & 4461,65 & - & - & -
\end{tabular}

Dari hasil uji coba analisis 1 prediktor diperoleh $\mathrm{F}_{\text {reg }}=57,060$ dengan $\mathrm{db} 1$ lawan 58 diperoleh $\mathrm{F}$ tabel 5\% sebesar 3,51 Jadi $\mathrm{F}$ hitung $>\mathrm{F}$ tabel $1 \%$ sehingga hasil penelitian dinyatakan signifikan. Artinya ada pengaruh yang sangat signifikan antara self concept $(X)$ terhadap self confidence $(\mathrm{Y})$ pada siswa Mts Miftahul Ulum Tunggulwulung Pandaan Pasuruan. Dengan demikian hipotesa yang berbunyi ada pengaruh self concept terhadap self confidence, diterima. Dimana self concept dapat digunakan untuk meramalkan self confidence pada Mts Mifathul Ulum sebesar $43 \%$, sedangkan $57 \%$ dapat diramalkan dari faktor yang lain.

\section{Diskusi}

$$
\text { Menurut Lauster }
$$

Kepercayaan diri dapat dipengaruhi oleh beberapa faktor yang dapat digolongkan menjadi dua, yaitu faktor internal dan faktor eksternal. Faktor Internal, meliputi Konsep diri yaitu Terbentuknya keperayaan diri pada seseorang diawali dengan perkembangan konsep diri yang diperoleh dalam pergaulan suatu kelompok. Menurut Centi (1995), konsep diri merupakan gagasan tentang dirinya sendiri. Seseorang yang mempunyai rasa rendah diri biasanya mempunyai konsep diri negatif, sebaliknya orang yang mempunyai rasa percaya diri akan memiliki konsep diri positif. 
Hal yang sama diungkapkan oleh Selain itu Iswidharmanjaya (2005) menyatakan ada tiga faktor yang mempengaruhi timbulnya self confidence yang mana salah satunya adalah Konsep diri Untuk menjadi pribadi yang memiliki percaya diri, seorang individu membutuhkan konsep diri yang positif. Konsep diri adalah gambaran yang dipegang seseorang menyangkut dirinya sendiri. Jika seorang individu sudah mengenal keadaan dirinya dan dapat menerima kelebihan dan kekurangan yang dimiliki maka individu tersebut akan memiliki percaya diri yang baik.

Berdasarkan hasil perhitungan memang $48 \%$ self confidence di pengaruhi oleh self concept. Sedangkan $52 \%$ faktor yang lain yang mempengaruhi self confidence seperti yang di ungkapkan oleh Lauster (2003) faktor ekternal juga mempengaruhi rasa percaya diri sesorang yang meliputi: Pendidikan, Pendidikan mempengaruhi kepercayaan diri seseorang. Anthony (1992) lebih lanjut mengungkapkan bahwa tingkat pendidikan yang rendah cenderung membuat individu merasa dibawah kekuasaan yang lebih pandai, sebaliknya individu yang pendidikannya lebih tinggi cenderung akan menjadi mandiri dan tidak perlu bergantung pada individu lain. Individu tersebut akan mampu memenuhi keperluan hidup dengan rasa percaya diri dan kekuatannya dengan memperhatikan situasi dari sudut kenyataan. Kedua Pekerjaan, Rogers (dalam Kusuma, 2005) mengemukakan bahwa bekerja dapat mengembangkan kreatifitas dan kemandirian serta rasa percaya diri. Lebih lanjut dikemukakan bahwa rasa percaya diri dapat muncul dengan melakukan pekerjaan, selain materi yang diperoleh. Kepuasan dan rasa bangga di dapat karena mampu mengembangkan kemampuan diri. Ketiga Lingkungan dan Pengalaman hidup, Lingkungan disini merupakan lingkungan keluarga dan masyarakat. Dukungan yang baik yang diterima dari lingkungan keluarga seperti anggota kelurga yang saling berinteraksi dengan baik akan memberi rasa nyaman dan percaya diri yang tinggi. Begitu juga dengan lingkungan masyarakat semakin bisa 
memenuhi norma dan diterima oleh masyarakat, maka semakin lancar harga diri berkembang (Centi, 1995). Sedangkan pembentukan kepercayaan diri juga bersumber dari pengalaman pribadi yang dialami seseorang dalam perjalanan hidupnya. Pemenuhan kebutuhan psikologis merupakan pengalaman yang dialami seseorang selama perjalanan yang buruk pada masa kanak kanak akan menyebabkan individu kurang percaya diri (Drajat, 1994).

Menurut Lauster (2003) didalam faktor internal selain dari konsep diri ada juga faktor internal yang lain seperti Harga diri, Meadow (dalam Sungkar dan Partini, 2015) Harga diri yaitu penilaian yang dilakukan terhadap diri sendiri. Orang yang memiliki harga diri tinggi akan menilai pribadi secara rasional dan benar bagi dirinya serta mudah mengadakan hubungan dengan individu lain. Orang yang mempunyai harga diri tinggi cenderung melihat dirinya sebagai individu yang berhasil percaya bahwa usahanya mudah menerima orang lain sebagaimana menerima dirinya sendiri. Akan tetapi orang yang mempuyai harga diri rendah bersifat tergantung, kurang percaya diri dan biasanya terbentur pada kesulitan sosial serta pesimis dalam pergaulan. Selanjutnya Kondisi fisik Perubahan kondisi fisik juga berpengaruh pada kepercayaan diri. Anthony (1992) mengatakan penampilan fisik merupakan penyebab utama rendahnya harga diri dan percaya diri seseorang. Ahli lain juga berpendapat bahwa ketidakmampuan fisik dapat menyebabkan rasa rendah diri yang kentara. Keempat adalah Pengalaman hidup, Kepercayaan diri diperoleh dari pengalaman yang mengecewakan adalah paling sering menjadi sumber timbulnya rasa rendah diri. Lebih lebih jika pada dasarnya seseorang memiliki rasa tidak aman, kurang kasih sayang dan kurang perhatian.

Menurut Iswidharmanjaya (2004) juga mengungkapkan faktor lain yang mempengaruhi self confidence selain dari konsep diri yaitu Proses belajar artinya untuk menumbuhkan rasa percaya diri dirasakan sejak usia dini. Pola asuh yang diberikan orang tua memiliki 
peranan yang besar dalam menumbuhkan percaya diri anak. Pola asuh yang diberikan meliputi kasih sayang, perhatian, penerimaan, serta yang paling penting adalah kelekatan emosi dengan orang tua secara tulus. Dengan adanya kehangatan dan asuhan dari orang tua, rasa percaya diri anak akan mulai bersemi. Kalau anak merasa dirinya berharga dan bernilai dimata orang tuanya, akan cenderung manjadi anakyang semakin percaya diri. Selain pola asuh, perilaku orang tua juga memiliki peran dalam proses pembentukan sikap percaya diri, karena biasanya anak yang masih kecil akan menirukan apa yang diperbuat oleh orang tuanya. Sebaliknya orang tua yang kurang memberikan perhatian, suka mengkritik, tidak pernah memberikan pujian ataupun tidak pernah puas melihat prestasi anaknya akan menurunkan percaya diri anaknya.. yang terakhir Interaksi dengan lingkungan Seseorang akan belajar mengenai diri sendiri melalui interaksi langsung dengan orang lain. Dengan berinteraksi, seorang individu akan memperoleh informasi mengenai dirinya dari orang lain. Tetapi jika tidak ada orang lain yang menilai maka individu tersebut tidak mengenal dirinya lebih dalam.

Dengan demikian self concept memang meberikan pengaruh terhadap self confidence atau kepercayaan diri, hal tersebut juga terbukti dari pengujian di sekolah di Mts Miftahul Ulum dengan hasil yang signifikan yang mana hal ini memberikan bukti bahwa self concept mempengaruhi self confidence.

\section{Kesimpulan}

Berdasarkan hasil penelitian ini dapat diambil kesimpulan bahwa ada pengaruh self concept terhadap self confidence di Mts Miftahul ulum Tunggul wulung Pandaan Pasuruan. Dari hasil uji coba analisis 1 prediktor diperoleh $\mathrm{F}_{\text {reg }}=57,060$ dengan $\mathrm{db} 1$ lawan 58 diperoleh $\mathrm{F}$ tabel 5\% sebesar 3,51 Jadi $\mathrm{F}$ hitung > $\mathrm{F}$ tabel $1 \%$ sehingga hasil penelitian dinyatakan signifikan. Artinya ada pengaruh self concept $(\mathrm{X})$ terhadap self confidence $(\mathrm{Y})$ pada siswa Mts Miftahul Ulum Tunggulwulung Pandaan Pasuruan. Dengan demikian hipotesa yang 
berbunyi ada pengaruh self concept terhadap self confidence, diterima. Dimana self concept dapat digunakan untuk meramalkan self confidence pada Mts Mifathul Ulum sebesar 43\%, sedangkan $57 \%$ dapat diramalkan dari faktor yang lain.

Saran

Penelitian ini diharapkan dapat menjadi agent of change (agen perubahan) dalam upaya peningkatkan self concept pada anak didik dengan bijaksana dan tepat guna dalam perkembangannya, karena dari hasil kajian diatas menunjukkan pegaruh self concept dengan self confidence sangat signifikan. hal ini dapat menjadi satu diantara berbagai macam metode untuk pola pengembangan siswa dalam khazana keilmuan secara mandiri dan tangguh sedangkan untuk peneliti selanjutnya Disarankan meneliti pengaruh variable lain yang berhubungan dengan faktor-faktor self confidence misalnya: harga diri, kondisi fisik, pengalaman hidup dan pendidikan

\section{Referensi}

Adiyanti. (2006). Psikologi Sosial. Bandung : PT. Rafika Aditama.

Alwisol. (2004). Psikologi Kepribadian. Malang: UM Press.

Anggelis, B. D. (1997). Percaya diri. Sumber sukses dan kemandirian: PT. Gramedia Pustaka Utama.

Anthony, R. (1992). Rahasia Membangun Kepercayaan Diri (R. Wiryadi, Trans). Jakarta: Binarupa Aksara.

Burns, R. B. (1993). Konsep Diri Teori, Pengukuran, Perkembangan dan Pe rilaku.

Alih Bahasa: Eddy. Jakarta: Penerbit: Arcan.

Centi, P. J. (1995). Mengapa Rendah Diri. Yogyakarta: Kanisius.

Drajat, Z. (1994). Remaja Harapan dan Tantangan. Jakarta: CV. Ruhama.

Hadi \& Putri. (2005). Bagaimana lebih memahami seorang diri remaja. Retrivied from: http://www.fpsi.unair.ac.id/files/ bagaimana $\% 20$ lebih\%20memaha mi\%20seorang $\% 20 \quad$ diri $\%$ 20remaja.pdf

Hurlock, E. B. (1999). Psikologi Perkembangan: Suatu Pendekatan Sepanjang Rentang Kehidupan. Alih bahasa: Istiwidayati \& Soedjarwo. Edisi Kelima. Jakarta: Erlangga

Iswidharmanjaya, D. (2004). Satu Hari Menjadi Lebih Percaya Diri. Jakarta: PT. Elex media komputindo. 
Kusuma, Y. D. (2005). Hubungan Antara Dukungan Sosial Dan Kepercayaan Diri dengan Kecenderungan Fobia Sosial pada Remaja Penyandang Cacat Tubuh [Skripsi]. Fakultas Psikologi Universitas Muhammadiyah Surakarta.

Kusumawati, R. (2009). Manajemen Karir dan Pengembangan Karir pada Organisasi tanpa Batas. Jurnal Ekonomi dan Bisnis, 4(7). Retrivied from: https://id.123dok.com/document/ ydv1591y-56739-id

Lauster, P. (2003). Tes Kepribadian (alih bahasa: D.H. Gulo). Jakarta: PT. Bumi Aksara.

Rakhmat, J. (2005). Psikologi Komunikasi. Bandung: PT. Remaja Rosdakarya.

Santrock, J. W. (1995). Life-Span Development: perkembangan masa hidup jilid 1, alih bahasa: Achmad Chusairi, Juda Damanik. Jakarta: Erlangga.
Sungkar, Y. \& Partini. (2015). Sense Of Humor sebagai Langkah Meningkatkan Kepercayaan Diri Guru PPL dalam Proses Belajar Mengajar. Indigenous: Jurnal Ilmiah Psikologi, 13(1). https://doi.org/10.23917/indigeno us.v13i1.2327

Suryabrata, S. (2010). Metodologi Penelitian, Jakarta: PT. Raja Grafindo Persada.

Wahid, A. G. (2014). Hubungan antara Konsep Diri dengan Belajar Mandiri pada Siswa Kelas IV SD Se-Gugus 1 Kecamatan Sedayu Kabupaten Bantul Tahun Ajaran 2013-2014 [Skripsi]. Fakultas Ilmu Pendidikan, Universitas Negeri Yogyakarta. Retrivied From: https://eprints.uny.ac.id.

Widarso, W. (2005). Sukses membangun rasa percaya diri "self confidence". Jakarta: Grasindo. 